Article

\title{
Luminous Bodies, Playful Children, and Abusive Grandmothers: Trauma, Dissociation, and Disorganized Attachment in the Early History of Great Perfection ( $r D z o g s$ Chen) Buddhism
}

\author{
Flavio A. Geisshuesler
}

Departments of Comparative Religion \& Asian Studies, Hebrew University of Jerusalem, Jerusalem 91905, Israel; flavio.geisshuesle@mail.huji.ac.il

Received: 28 January 2020; Accepted: 5 March 2020; Published: 7 March 2020

\begin{abstract}
This contribution explores the development of the highest teachings of the "Old School" (rnying ma) of Tibetan Buddhism, known as the Great Perfection (rdzogs chen). Between the tenth and the twelfth centuries, when the "New Schools" (gsar ma) rose to prominence and challenged the legitimacy of the established ones, Dzogchen underwent radical transformations and grew into a complex of contradictory voices. Unlike existing scholarship, which relies exclusively on textual-philological analysis to elucidate the conflictual relationships between sub-traditions like the Mind Series (sems sde), the Seminal Heart (snying thig), and the Crown Pith (spyi ti), this article proffers a transdisciplinary perspective, which complements history with psychological investigations into myth and cognition. Introducing research from cognitive science, trauma studies, attachment theory, and dissociation, it scrutinizes fascinating Dzogchen myths of luminous bodies, playful children, and abusive grandmothers. Ultimately, this transdisciplinary approach results in a new interpretation of the early history of the Great Perfection, as marked by an internal division in the tradition that was the direct result of a historical trauma, which was first processed, then internalized, and finally perpetuated.
\end{abstract}

Keywords: psychology of religion and spirituality; attachment trauma; dissociation; trauma myths; Great Perfection Buddhism

\section{A Psychological Perspective the Development of Great Perfection Buddhism}

The study of early Buddhism in Tibet is not a simple endeavor. Besides the scarcity of historical data, premodern religious traditions rarely made clear distinctions between mythical imagination and historical fact. In this article, I explore the historical origin of one particular form of early Buddhism on the central Asian plateau, namely the famous tradition known as the "Great Perfection" (rdzogs chen, Dzogchen).

The highest teaching developed within the so-called school of the "Ancients" (rnying ma, Nyingma), the Great Perfection is both one of the most famous and one of the most controversial Buddhist traditions of Tibet. This is true both from a diachronic and from a synchronic perspective. From a diachronic point of view, Dzogchen became an independent religious tradition on the Tibetan plateau over the course of what is, without a doubt, one of the most creative moments in the history of Buddhism, namely the so-called "later dissemination of the teaching" (bstan pa phyi dar, late tenth-twelfth centuries). More specifically, the historical progression of the Great Perfection testifies to radical transformation between its earliest textual sources from the ninth and tenth century and its most influential scriptures, the so-called Seminal Heart (snying thig), written sometime between the eleventh and the twelfth centuries. Synchronically speaking, even after the Dzogchen evolved into its dominant form of the 
Seminal Heart by the twelfth century, its core ideas and practices were not marked by coherence, giving rise to repeated conflicts between opposing fractions of the tradition.

To account for the divergences on both axes, the Great Perfection has used a variety of systems to categorize its sub-traditions. For instance, in order to bring cohesion into their tradition's uneven historical development, Dzogchen thinkers introduced a distinction known as the so-called Three Series (sde gsum), consisting of the Mind Series (sems sde), the Space Series (klong sde), and the Instruction Series (man ngag sde). Similarly, controversies regarding its internal tensions frequently took on the form of a debate between the so-called Three Piths, consisting of the Transcendent Pith (a ti), Crown Pith (spyi ti), and Ultra Pith (yang ti).

Existing scholarship on these formative years of the Great Perfection has primarily relied on philological and textual-critical analysis, and attempted to systematically collect and organize these early references to the tradition's terminology, lineal transmission and internal division (Karmay 2007; Germano 1994, 2005; Van Schaik 2004). ${ }^{1}$ By contrast, in this study, I offer a more holistic analysis of the formative years of the Great Perfection by integrating such historical considerations with a careful examination of the mythical narratives contained within the Seminal Heart Great Perfection. This tradition's body of scripture, which is made up of The Seventeen Tantras, emerged during the eleventh and twelfth centuries and is famous for its sophisticated myth of cosmogony as a moment of rupture, diversification, and estrangement. Even though the coordinated reading of myth and history is a staple in the study of other Tibetan traditions-such as the closely associated tradition of the Kālacakratantra (Newman 1991, p. 80)—such an approach has only recently found traction in the study of Dzogchen (Geisshuesler 2019b).

This being said, the association between the controversial status of the Ancients' teachings amongst the rapidly changing religious landscape on the Tibetan plateau and the Great Perfection mythology has been insinuated previously. Consider, for example, the following considerations by David Germano:

Even within the context of Nyingma communities, and more so in the wider Tibetan religious landscape being reshaped by the modernist movement, these teachings were quite controversial. The uniqueness of the Seminal Heart tradition in the context of the Great Perfection is due equally to its complex mytho-philosophical presentation of the cosmos' unfolding within an explicitly soteriological and psychological framework, as well as its incorporation of complex visual images and imaging into its mainstream (though in a quite different style than traditional tantric praxis). (Germano 1994, p. 270)

Germano's account also points to the third thread that will be used to weave the tapestry of this study, namely the human psyche. In fact, while scholarship has previously identified the Seminal Heart as religious survival strategy in response to the increasing marginalization of the "Ancients" during the rise of the "New Schools" (gsar ma, Sarma) (Davidson 2005, pp. 228-29), my investigation is the first to explore how the Great Perfection's mythical narratives and historical development were shaped by trauma. Trauma-a "wound" or "injury" in its original meaning-is a notion that is used to describe physical harm, individual psychological circumstances, but also socio-cultural events (Caruth 1995, 2016; Tal 2004; Rippl et al. 2013; Alexander 2004). Put differently, although trauma is conventionally conceived of as a result of actual threat to bodily integrity, it has also been explored in narratives, where it can be described as "symbolic" or "collective" in nature. More broadly, trauma "might be defined as involving threats to the integrity of important individual and communal beliefs and systems of meaning, critical to the individual's and group's concepts of life and selfhood" (Rodger and Steel 2016, p. 60).

Although the most important studies on collective trauma have focused specifically on the Holocaust (LaCapra and Collection 1994; Yehuda et al. 2002; Giesen 2004; Yehuda et al. 2016; Mazur

1 Note that some authors have suggested a non-evolutionary model of the Great Perfection's early history, proposing a greater antiquity of the Seminal Heart Scriptures (e.g., (Achard 1999, 2012)). 
and Vollhardt 2016), scholars have also studied it in various contexts, such as the Apartheid regime (Sideris 1998; Adonis 2016), the formation of the states of India and Pakistan (Yusin 2009; Debs 2013; Hanif and Ullah 2018), the African American experience in North America (Eyerman 2001), indigenous populations with traumatic histories (Bombay et al. 2017), and even cross-culturally (Alexander 2012). Indeed, cultural trauma has even been adopted to shed light on the situation of modern Tibet (Kapstein 1998; Terheggen et al. 2001; Kolas and Thowsen 2005; Hussain and Bhushan 2011, 2013; Gayley 2017).

This being said, trauma has not been invoked in the discussion of the early history of the Tibetan people and the myths that were articulated during those years. This is a lost opportunity, as the correlation between trauma and the creation of narratives has been a theme of investigation in the study of religion. Scholars have not only pointed to the fact that modern religious narratives serve the purpose of overcoming trauma (Durà-Vilà et al. 2013), but have also shown that old scriptures-such as the Bible-bear the mark of trauma (Birnbaum 2008). Benjamin J. Abelow went as far as expanding his research into the New Testament by arguing that even Hindu and Buddhist ideas, such as karma and reincarnation, were developed out of experiences of childhood trauma (Abelow 2011). James Rodger and Zachary Steel further expanded on the correlation between trauma and culture by noting that "traumatically fragmented pieces of self might be shaped and contained by local cultural beliefs and practices," even claiming that "a fragmented-self may indeed be more susceptible to cultural-shaping," with religious narratives providing a sort of "glue" (Rodger and Steel 2016, p. 156).

Inspired by emerging research that argues that "collective reactions to a history of trauma are similar in many respects to individual post-traumatic reactions" (Hirschberger 2018, p. 5), I have recently argued that the Great Perfection's mythic narratives display a variety of trauma symptoms that we also find in individual psychology (Geisshuesler 2019b). In this same investigation, I also showed that the early history of Dzogchen was marked by two specific socio-political traumas, namely the collapse of the empire in the late ninth and the rise of the New Schools, starting in the eleventh century.

In this study, I focus particularly on the second socio-political crisis and draw on a different set of theories developed within psychology and cognitive science in order to offer a comprehensive account of how the Seminal Heart Great Perfection first processed, then internalized, and finally perpetuated trauma through its mythical narratives. More specifically, I introduce cutting-edge research from attachment theory and structural dissociation and argue that the Great Perfection developed as a "dissociated totality;", that is to say, a tradition that is both a unified totality and a collection of dissociated currents. In so doing, I offer a compelling account of the reasons, functions, and mechanisms of the diachronic and synchronic contradictions to be found in the Great Perfection.

It is quite apparent that religious studies and the humanities, on the one hand, and the cognitive sciences and the natural sciences, on the other, are characterized by different epistemological presuppositions. My approach is experimental as it moves fluidly in between different modes of dialogue: in some instances, I perform a hermeneutically open association of history and cognition, in which cognitive theories provide me with broad metaphors that allow me to illuminate the Great Perfection. In other moments, research from the cognitive sciences enables me to submit possible explanations for the precise mechanisms underlying certain phenomena recorded in the mythical-historical origins of the Great Perfection.

The article is divided into three sections that follow the mythical and historical development of the Great Perfection to (1) commence with the processing of trauma, (2) to proceed to the imprinting of trauma, and (3) to finally culminate in the perpetuation of trauma.

\section{The Processing of Trauma, the Creation of the Self, and the Universality of Existential Suffering}

According to the tradition's own accounts, the early Great Perfection scriptures originated in India where they were transmitted through an unbroken lineage that began with Vajrapāni and progressed to the obscure Garab Dorjé ( $d g a^{\prime}$ rab rdo rje, Skt. *Vajraprahe), before moving through the hands of no less enigmatic figures like Mañjuśrīmitra, Śrīsiṃha, Jñānasūtra, to finally make it all the way to Tibet, where it arrived in the eighth century thanks to the Indian masters Vimalamitra and Padmasmbhava, 
as aided by such Tibetan translators as Vairocana. However, there is no literary, archeological, or historical evidence of a movement by the names of Atiyoga, Mahāsandihi, or Mahāsampanna, the Sanskrit terms that could be used to translate Dzogchen, in the Indian Buddhism that was transmitted to Tibet during the "early dissemination" (snga dar) of the teachings in the seventh and eighth centuries.

This is why we can conclude that the Great Perfection originated in Tibet in the ninth century with the composition of what would later be classified as the Mind Series. Beginning as a collection of quite short texts known as The Eighteen Texts of the Mind Series (sems sde bco brgyad), they would later proliferate and culminate in such masterpieces as The All-Creating King Tantra (Tib. kun byed rgyal po'i rgyud, Skt. Kulayaräja Tantra). The Mind Series texts were dominated by one central theme, namely the enlightened mind, which was said to be "empty" (stong pa), "radiant" ('od gsal), and "originally pure" ( $\mathrm{ka} \mathrm{dag}$ ). In line with these priorities, the earliest strata of the Great Perfection rejected a series of elements that would become the staples of the tradition in the eleventh century, particularly visionary practices involving light images, mantric technology, and subtle body anatomy. Instead, early Dzogchen is marked by naturalism, negation, and absence.

As I noted, another innovation of the Seminal Heart was its elaborate myth of cosmogony. I have shown elsewhere that existing scholarship has generally underestimated the traumatic nature of this mythic narrative (Geisshuesler 2019b, p. 4). In fact, both the Great Perfection itself and the existing scholarship on the myth have generally described the so-called "epiphany of the ground" (gzhi snang) in terms of its positive potential (Achard 2005, 2008; Deroche and Yasuda 2015). At the same time, however, it must be noted that the myth begins in a decidedly startling fashion: in the story, we read about a "ground," imaged as a perfectly self-contained and luminously shining "youthful body in a vase," which dramatically cracks open to emanate a variegated array of light rays. After the epiphany of mandalic shapes of light, the radiation of luminosity gradually loses its transparency, solidifying more and more until it takes on the form of living beings and the universe of material objects as we know it.

While it has rightly been noted that this account displays the later tradition's fascination with the "early history of the Universe" (Germano 1992, p. 60), that it also imagistically describes the early history of the Great Perfection itself is usually overlooked. More specifically, the ground can be associated with the Mind Series. Telling the story of what the Great Perfection looked like before its birth, the Seminal Heart mythically illustrates the Mind Series' core teaching, the enlightened mind, in terms of the "ground" (gzhi), which precedes the genesis of the universe as we know it. The ground, in fact, depicts the moments before existence comes into being, the moment before the "big bang." In The Seventeen Tantras, it is even imagined as a "youthful body in a vase" (gzhon nu bum pa'i sku), a sort of flask, which contains an essence of ever-youthful freshness.

There occurs, of course, a series of other parallels between the ground and the Mind Series. Just as the Mind Series circumscribed the enlightened mind as empty, luminous, and primordially pure, the Seminal Heart scriptures outline the ground in terms of three qualities: "empty essence" (ngo bo stong pa), "radiant nature" (rang bzhin gsal ba), and "all-pervading compassion" (thugs rje kun khyab).

As for the first, just as the Mind Series is premised on naturalness, negation, and absence, the ground is primarily defined in negative terms: it is "free from extremes" (mtha' bral), "indeterminate" (lung ma bstan), "unformulated" (spros bral), "aimless" (gtad med), "unobstructed" (zang thal), and "unimpeded" (ma 'gags pa). The ground's rejection of elaboration is particularly directed at abstract philosophy and intellectual speculation: in The Pearl Necklace Tantra, for example, we read of the ground in the form of an explicit rejection of what "has been designated as 'intellect' (blo)," noting that "there is no collection of names (ming) and letters (yi ge)" and that "it can't be established in terms of mind (yid) and mentation (sems)" (MTP, 461.1). ${ }^{2}$ Similarly, The Six Spaces Tantra states that "since

2 All translations from Tibetan are my own. blo zhes kun tu ma mtags pas/ [ . . ] ming dang mi ge'i tshogs med pas/ [ ... ] sems dang yid du ma grub pas. 
apprehendable objects to be grasped are absent ('dzin pa'i gzung yul med), conceptual apprehension does not take place" (LDG, 178.6). ${ }^{3}$

The second quality that ties the enlightened mind of the Mind Series to the Seminal Heart's ground is their "radiant nature" (rang bzhin gsal ba). As Hatchell put it, "while the ground is described in negative terms, as being empty of reality/unreality and so forth, it is not an emptiness of static darkness, but one that is alive with radiance and light" (Hatchell 2014, p. 99). In The Seventeen Tantras, the energy is furthermore qualified as "spontaneously productive" (lhun grub) and frequently expressed through metaphors of light. The ground is marked by "(dis)play" (rol pa), "radiance" (gdangs), "effulgence" (ye gdangs), and "radiant light" ('od gsal). The myth of origin of the Great Perfection, in fact, is not only concerned with the ground in its primordial interiority, but also in the "way in which the ground epiphanizes in spontaneous presence" (lhun grub gzhi snang gi shar tshul).

Finally, the ground's characterization as "all-pervading compassion" corresponds closely to the idea of the "primordial purity" found in the Mind Series. In fact, the "epiphany of compassion" is epitomized "as the cloudless sky" and defined as the "natural condition of original purity" because it is "devoid of any limitations, having not fallen in any direction" (RRS, 529.5). ${ }^{4}$ As something that has been there "before", the rupture, the depiction of the ground, stands for that which is ancient over what is modern. Indeed, the ground is frequently also called the "original ground" (gdod ma'i gzhi) and explicitly described as "originally pure" ( $\mathrm{ka} \mathrm{dag}$ ). Although scholars are correct in pointing out that this expression should not be regarded simply as a temporal definition of the ground (Kapstein 2000, pp. 167-70), there is no doubt that such a priority is at least part of the concept.

On the other hand, the ground is associated with a type of timelessness or eternity, which is reflected in its alternative description as "atemporal" (dus med) or "indeterminate time" (ma nges pa'i dus), or "fourth time" (dus bzhi pa). If I read the Seminal Heart's mythical narrative in order to show certain parallels between the Mind Series and the mythical ground, then the latter's non-temporality points to a specific aspect of the relationship between the early and the later form of the Great Perfection. In fact, by setting it outside of time, the Seminal Heart, at least implicitly, expresses its belief that Dzogchen only truly came into existence with its very own emergence, and not with the Mind Series that existed well before the development of the Seminal Heart tradition.

This, indeed, is connected to the larger religious landscape of the Tibetan plateau as the "emergence of the modernist movements from this point onwards resulted in new religio-cultural heterologues sparking a series of crises and transformations in pre-existing Buddhist groups (beginning with their constitution as the 'ancients')" (Germano 1994, p. 266). Historically speaking, this is the truest meaning of the myth of cosmogony. It mythically mirrors not only the radical transformation of the Great Perfection tradition, but the very emergence of the school of the Ancients and the Seminal Heart tradition.

Similarly, just as the historical process "altering the very identity of the Great Perfection" has been envisaged as a "pushing outwards," or "fluctuat[ing] outwards" of boundaries, the myth narrates the cosmogony as a transcending of self-contained limitations in the form of an externalization. In The Tantra of the Lion's Perfect Expressive Energy, for example, we find a reference that points to the fact that both the fundamental nature of the enlightened mind, the dominant theme of the Mind Series, and the ground, the image developed within the later tradition, undergo profound transformations at the moment of birth; both of which are likened to the hatching of a peacock's egg ( $r m a$ bya'i sgo nga):

Awareness abiding within the ground is the perfectly complete triad within wisdom's expanse, just like a peacock's egg, its inner light is revealed as the clarity of wisdom. Awareness

\footnotetext{
'dzin pa'i gzung yul gang med phyir/ rnam par rtog pa'i 'dzin cha med.

gzhi ka dag chen po zhes bya ste/ ngo bo rang bzhin thugs rje rnam pa gsum du gnas so/ ng obo mi 'gyur ba'i ye shes/ ma 'gags par gsal ba gzhon nu bum sku'i gnas lugs zhes bya'o/ rang bzhin 'od lnga'i snang ba ma 'gags pa'o/ thugs rje'i snang ni/ dper na sprin med pa lha bu'o/ de ni ka dag gi gnas lugs zhes bya ste/ gya gar yang ma chad/ phyogs gar yang ma lhung ba'o.
} 
shining forth on the path is like rainbow colors. Awareness reaching its extent resembles the peacock's chick bursting out of the egg (SGT, 372.4). ${ }^{5}$

This emphasis on these early moments of existence are ultimately an expression of the Great Perfection's larger inquiries into the creation of its own self; or, as the tradition itself would call it, the "epiphany of the self" (rang snang). The Dzogchen myth argues that as the ground epiphanizes, we witness the birth of selfhood. In the The Blazing Lamp Tantra, for example, we read that:

From within this abiding ground, the seed of straying and its causes are the aspect of lucidity that has slipped outward [to] suddenly epiphanize objectively as the mind that holds to a "self" (bdag tu bzung) [ ... ] In this way, the objective sphere is apprehended as a "self" (bdag bzung) (DYC 45.6). ${ }^{6}$

The ground's epiphany ( $g$ zhi snang), the breaking and opening up of the vase, its slipping outward (phyir shor), its projecting into a vast "expanse" (dbyings), rather paradoxically, leads into the "capturing" (bzung) of the "self" (bdag). In The Reverberation of Sound Tantra, we read:

The ground and cognition become sullied and the revolving process of apprehended objects (gzung) and sensory faculties (dbang po) sets in. The conditions are that, through the objective sphere and the apprehension factor ( $g z u n g ~ c h a)$, there come to be individual distinctions based upon their respective boundaries. [... ] The psychic energy in question involves subjective apprehensions ('dzin pa rnams) that are flickering, subsiding, and prolific. The pollution lies in its apprehension ('dzin pa) in a stained fashion, such that your own self-identity (rang rgyud) is fettered (bcing) by this way of comprehending. Even though that which is comprehended ( $g z u n g b a$ ) is not what it seems, you become tightly bound (dam $d u b c i n g b a$ ) by clinging to its veracity $(\mathrm{GTG}, 142.6){ }^{7}$

In psychology and cognitive science, the study of the early years of human existence is one of the specialties of developmental psychology. One of the most important areas of inquiry within this field is attachment theory, which has not only proven to be well-suited for cross-cultural investigations (Van Ijzendoorn and Sagi-Schwartz 1999; Otto and Keller 2014), but is also relevant to the study of how humans create their sense of self. While many other perspectives that deal with social cognitive development exist (e.g., theory of mind), this article centers on attachment research because it effectively shows that humans create their sense of selfhood by means of two radically opposed tendencies when interacting with the environment: attachment and aversion.

Attachment research, of course, is relying here on a universal binary orientation of all of human and animal life, which is well known to researchers of cognition. Scholarship has identified these two attitudes—attachment and aversion—as "the two major categories of psychobiological systems that make up personality" (Van der Hart et al. 2006, p. 41). The first category is comprised of systems that are seeking to approach stimuli that we consider attractive, such as nurturing, food or companionship. The second category, by contrast, consists of psychobiological systems that are geared towards avoiding or fleeing from stimuli that we consider adverse and threatening to our well-being.

Since these orientations have been evolutionarily designed to guide our action in a goal-directed manner, they are also known as "action systems" (Arnold 1960; Frijda 1986). Action in this context, however, has to be understood from a broader perspective. In fact, it includes a type of cognition

5 gzhi la gnas pa'i rig pa ni/ ye shes dbyings na sku gsum rdzogs/ dper na rma bya'i sgo nga bzhin/ nang 'od ye shes gsal bar bstan/ lam la 'char ba'i rig pa ni/ dper na 'ja' tshon lta bur bstan/ mtha' la skyol ba'i rig pa ni/ dper na rma bya'i phru gu sgo nga nas/ brdol te don pa lta bu'o.

6 de ltar gnas pa'i gzhi de las/ rgyu dang 'khrul pa'i sa bon ni/ gsal ba'i cha ni phyir shor bas/ [ ... ] yid tsam phyir 'gyus snang cha la/ yul de bdag tu bzung ba'i blos/ [ ... ] de ltar yul la bdag bzung ba'o.

7 gzhi dang shes pa sbags pa dang/gzung dang dbang po 'gor tshul lo/ rkyen ni yul dang gzung cha las/ mtha' dang mtha' yi byed pa dang/ [ ... ] shes pa 'ju dang yal pa dang/ mched par 'dzin pa rnams yin no/ sbags pa dri mar 'dzin pa ste/ shes byas rang rgyud bcing pa'o. gzung ba ma yin sa la yang/bden pas dam du bcing ba'o. 
which is running an unconscious type of surveillance program that is always active, even when we are concerned with other issues. As the cultural psychologists working with experiments of priming have demonstrated, this unconscious monitoring is constantly occupied with the evaluation of our environment as either "good" or "bad." John Bargh recently put it like this: "This initial reaction colors everything that comes after it: good or bad, stay or go, like or dislike, approach or avoid" (Bargh 2017, p. 127).

As Dominic Sur correctly noted, in Buddhism, the path is imagined along the lines of one particularly popular distinction, namely that between "acceptance and rejection" (blang dor) (Rong-zom Chos-kyi-bzang-po 2017, p. 227). In fact, the dynamism of acceptance and rejection, the "adopting" (blang) of certain things, and the simultaneous "discarding" (dor) of others, serves as a sort of membrane through which human beings establish the homoeostatic balance that we call "self." Thus, it seems that the Great Perfection advocates for a conspicuously parallel conception of how human existence is, by definition, marked by a certain degree of suffering to mental dysregulation. The mind of the humans is predisposed to a painful existence because it forms its "self" through interpersonal relationships, which can be illustrated as a "boundary making" with what is "other." David Germano beautifully projects this unfolding, as he writes:

... should it err in interpreting the lights as some unknown, vaguely threatening Other divorced from its own intelligence as a proto-subjectivity, it "strays" into the harrowing world of a lonely alienated "subject" surrounded by discrete "objects" and other subjects that create a basis [sic] tension that the "subject" seeks to resolve by alternately "possessing" and "destroying" the others through actual and imaginative attempts at union and negation (i.e., love and war). (Germano 1992, p. 70)

Similarly, in The Mirror of the Heart of Vajrasattva, we find a first-hand illustration of this interpersonal dimension of self-emergence:

The ground's essence is empty, its nature is radiant, and its compassion has the capacity to epiphanize (snang nus pa) to sentient beings. When the aspect of ignorance cognitively grasps ('dzin byed) for a mere instant, darkened cognition reflects: "Have I ( $n g a$ ) emerged form over there (pha gi) or has that over there (pha gi) emerged from me (nga)?" (DJS, 332.4). ${ }^{8}$

Our passions are jailors, craving and aversion their chains, the self that is bound by them becomes our most fundamental prison. Not only that, by separating ourselves from the "other", to be either rejected or craved, we imprison ourselves even further within a world of objects that dominate us seemingly at will. As Alan Mittleman, in his study of Isaac Breuer's philosophy, once submitted:

After the I divorces the representations and recognizes them as things-in-themselves, it finds that it has become entrapped in the world-in-itself. Feeling is a state of enslavement (Knechtschaft) that presents an ongoing contrast to the state of sovereignty (Herrschaft) otherwise enjoyed by the I. Breuer is very much concerned to develop this fundamental dialectic of the human experience. Man's most simple and continual experience of lordly freedom continually resolves into its opposite: bondage to the things of this world. (Mittleman 1990, p. 59)

In the Great Perfection, another image used for the initial self-emergence is the confusion regarding faces. The scriptures often refer to straying as a form of "non-recognition" (ngo ma shes). However, far from being purely a perceptional issue, the literal meaning of the Tibetan expression "non-recognition" points to its interpersonal nature: non-recognition is nothing other than the "not-knowing" (ma shes) of

8 gzhi de ngo bo stong pa/ rang bzhin gyis gsal ba/ thugs rje sems can la snang nus pa'o/ de nas nang 'dzin byed kyi shes pa ma rig pa'i cha las byung ba breng tsam 'gyus pa las/ shes pa spun pos pha gi las nga byung ngam/nga las pha gi byung snyam pa'i shes pa byung ba tsam gyis 'khrul lo. 
the "face" (ngo), which culminates in a type of "insanity" ("khrul pa). In her famous book on trauma, Prisoners of Childhood (1981), Alice Miller enlists an image that was originally proposed by Donald Winnicott to limn this type of non-recognition from the viewpoint of a child:

The mother gazes at the baby in her arms, and the baby gazes at his mother's face and finds himself therein [... ] provided that the mother is really looking at the unique, small, helpless being and not projecting her own expectations, fears, and plans for the child. In that case, the child would find not himself in his mother's face, but rather the mother's own projections. This child would remain without a mirror, and for the rest of his life would be seeking this mirror in vain. (Miller 1981, p. 27)

In the psychology of attachment, this type of confusion is generally attributed to the contradictory behavior of the attachment figure. In fact, in childhood, the "face" of the other is oftentimes both the primary source of comfort and warmth and a cause of fear and anxiety (Main and Hesse 1990). This effects a type of biological paradox, a double-bind: on the one hand, our bodies are made to seek physical closeness in order to receive nourishment, protection, and soothing; on the other hand, this biological need puts us into an impossible position because it forces it to approach the very source of the terror and trauma that we need to avoid in order to survive. Mary Main and Erik Hesse, early attachment researchers, have called this unresolvable dilemma-which cannot help but give rise to disorganized attachment—-the "fright without solution" (Hesse and Main 2000).

\section{The Imprinting of Trauma and the Rise of the Seminal Heart}

Historically speaking, in the renaissance of Tibetan culture, occurring from the late tenth century to the early twelfth century, Dzogchen was so completely transmuted that its adherents would not recognize themselves in its most mutated forms. Expressed differently, as the New Schools imported advanced tantric materials on meditative technologies and subtle body theories, putting unprecedented pressures on the increasingly marginalized group of the Ancients, the Great Perfection became divided within itself. More specifically, the internal dissociation was the result of the Dzogchen masters' difficulties defining themselves, as they took on divergent attitudes in response to the rise of this powerful "other." While the Mind Series reacted with aversion, remaining firmly grounded within their rhetoric of simplicity, negation, and naturalness, the Seminal Heart adopted a more receptive attitude towards the new teachings.

In both cases, furthermore, the outgrowths of trauma become progressively more palpable as we encounter increasing isolation, fragmentation, and multiplication. Arguillère, in his analysis of the "error" ('khrul pa), remarks something similar as he attributes two distinct meanings to this term: On the one hand, it is a being lost in the sense of setting out on the wrong paths, making mistakes, and taking wrong choices. On the other hand, it is a being lost in a more existential sense as one is losing sight of one's self in a process of alienation (Arguillère 2007, p. 410). As human beings repeatedly make the same "error" of misrecognition, they gradually lose sight of their own selves, becoming alienated from their true nature, dissociated within their own personalities. As Alice Miller phrased it, "in what is described as depression and experienced as emptiness, futility, fear of impoverishment, and loneliness can usually be recognized as tragic loss of the self in childhood, manifested as the total alienation from the self in the adult" (Miller 1981, p. 33). David Higgins discovered that the error is closely tied to the nature of human beings (sems can, lit. "minded beings") as they are "animated by, controlled by, mind" (Higgins 2013, p. 132):

Mind is what drives the recurrent habitual patterns of cyclical existence, the automatized routine of actions and reactions that propel beings inexorably from one situation to the next. It is in this sense that the Mu tig phreng ba refers to human beings as automatons, self-operating machines ('khrul 'khor) animated by mind. The simile poignantly captures the feeling human beings often have of losing control of, or even being controlled by, their own randomly occurring thoughts. (Higgins 2013, p. 132) 
The Great Perfection's emphasis on transgenerational processes suggests that the long-term consequences of disorganized attachment in the form of structural dissociation could also be investigated from a collective perspective. In other words, if early trauma in individuals leads to a structural dissociation of the personality, then a cultural tradition's emergence in a context of crisis could have ramifications for its future enlargement as a tradition with a high degree of internal tensions and a multitude of contradictory orientations. Historically speaking, the contradictory frames of reference in the Great Perfection were forged over time as the Nyingma groups that survived the dark age transmitted their teachings according to such a disorganized pattern of attachment. During the age of fragmentation, as Cabezón rightly noted:

In the absence of a centralized polity, power was wielded chiefly by the remnants of the royal family or by the more powerful clans that had been part of the royal court. Different factions held power in different regions of Tibet. They often competed with one another with the hope of gaining enough wealth and influence to usher in a new imperial age, but this was never to be. (Cabezón 2013, p. 1)

The tantric adepts, the Ngagpa practitioners of the mantra, who passed their teachings from father to son throughout the dark period and beyond, felt both the need for faithful continuity with the tradition of their forefathers (or -mothers) and the requirement to adjust and innovate in light of the new challenges that they faced as Tibet was flooded with new teachings from South Asia. The Great Perfection trauma is a transgenerational wound that got encoded in a mythic narrative and perpetuated over the course of several decades, if not centuries.

More specifically, the Great Perfection changed dramatically with the rise of the Seminal Heart as it challenged the Mind Series' radical prioritization of naturalness, simplicity, and effortlessness with narratives, doctrines, and practices of a more complex nature. Dzogchen adherents in the eleventh century started to adopt some of the elaborate contemplative practices, subtle body manipulations, pantheons of wrathful and erotic Buddhas, and death motifs as we find them in the tantric system of the New Schools.

Thus, the Great Perfection offers a plausible answer to the question of what can happen when a religious tradition suffers trauma: under the socio-political pressures due to the rise of the New Schools, Dzogchen adjusted to the new circumstances by integrating ideas that did not originally belong to its own religious matrix. In what must be regarded as the most creative attempt to deal with the early history of the Great Perfection, David Germano followed similar intuitions:

This carved out space of absence thus functioned partially to maintain a bounded zone in which Tibetans could think, resisting the pressure of domination from the flood of Indic culture through rhetorical negation, and then while still holding it at an arm's distance, perform the alchemy of cultural assimilation. (Germano 1994, p. 210)

A key advantage in turning to the psychology of attachment is its ability to interpret the internalization of trauma. In psychology, it is a well-recognized fact that the first moment of traumatic bewilderment initiates a perpetual mental state in which the cognitive errors of the beginning are repeated over and over. Attachment theorists, indeed, have shown that trauma experienced during childhood sets up patterns of interaction with the environment that last for a lifetime. Cognitive scientists call these long-term patterns, which our minds generate based on generalizations of experiences, "mental models."

Robust experimental evidence from attachment research has demonstrated the significant continuities in mental models, perception of self and other, and general attachment strategies between early life and adulthood (Dalenberg et al. 2012; Hamilton 2000; Lyons-Ruth et al. 2006; Carlson et al. 2009), and highlighted the continued risk of psychosis throughout the lives of victims of childhood trauma (Morrison et al. 2003; Read et al. 2008). Such findings of continuity between childhood and adult life have been confirmed and complemented by other fields of research. Epigenetics, for 
example, has proven that childhood experiences produce permanent transformations in the molecular structure of individuals, impacting the activation of genes in adulthood and beyond (Meaney 2001; Guénard et al. 2013). Many of these studies have paid particular attention to how traumatic experiences during childhood impacted the future of sufferers (McGowan et al. 2008; Perroud et al. 2013).

In Buddhist terms, the "mental models" of epigeneticists and attachment theorists could be translated into "karmic mental models:". Here, too, we are dealing with a cognitive disposition that results not only from our current experiences in this life, but also lives across generations, as it is passed along from one life to the next as a subtle form of energy.

The Great Perfection is a tradition that is highly attuned to the importance of time and memory in the evolutionary unfolding of our "selves." Although they did not fully appreciate the fundamental role of trauma in the DNA of the Great Perfection, several scholars have implicitly referenced the transgenerational role of human straying by analyzing the term "error" ('khrul pa). In fact, this expression-ranging in its semiotic meaning from a simple perceptual "error," to a continuous "erring" (as in Higgins' "machine" of error), all the way to a full-blown "mental disorder"—is also suitable for accounting for the cultural form of madness that is samsāric existence. David Higgins, for instance, transcribed that Longchenpa relied on the homophonic association between "to err, go astray" ("khrul $p a)$ and "to manifest, emanate" (sprul) in order to invoke the dual nature of the ground (gzhi) as something that can lead to "freedom" ('grol ba) and to "errancy" ('khrul pa) (Higgins 2013, p. 180). Janet Gyatso, whose work is generally more attuned to the diachronic vicissitudes of religious thought, zeroed in on the exact same association in the work of one of the main promulgators of Longchenpa's work, namely Jigme Lingpa ('jigs med gling pa, 1729-1798). She notes that this great Dzogchen master "punningly switches between the near-homophones for 'delusion' ('khrul) and 'emanation' (sprul or 'phrul); all three are pronounced something like 'trul')" (Gyatso 1998, p. 217).

More specifically, time appears frequently as a contributing circumstance to the trauma of the epiphany of the ground. In The Tantra of Great Beauty and Auspiciousness, for example, we read: "In dependence upon time, not recognizing the naturally self-emergent light, cognition begins to fixate on something other than the true nature, and that becomes the immediate condition" (KSD, 216.4).

After the initial shock of the bursting vase of youth, the narrative of the epiphany proceeds to detail how this originally unified source of light splits into a multitude of factions. The Dzogchen scriptures find several ways to imagistically portray this process of rupture into the architecture of personality. Frequently, they symbolize it through a solidification of the rainbow-colored lights and the increasing concreteness of external reality. As they are born out of the light gushing from the broken vase, they "stray." Deteritorrialized and confused, human beings look around themselves without recognizing themselves as part of the display of the ground's light energy, and so they become imprisoned in their own reified conceptions of selfhood. To use the words of Arguillère, the epiphany of the ground turns "the one that is multiple to the multiple ones" (Arguillère 2007, p. 411).

In the Great Perfection myth of origin, the tendency to split one's personality into various separate parts also finds expression in the prolific multiplication of beings that are said to epiphanize out of the body of light following its fragmentation. Of course, the experience of a self which splits into pieces can serve as an accurate conceptualization of what happens when individuals experience psychological trauma. In an article on ego-fragmentation and dissociation, for example, the well-known Swiss psychopathologist Christian Scharfetter wields the metaphor of a "self" made of glass—which shatters in response to stress-in order to understand how an individual's psyche responds to trauma (Scharfetter 2009). Similarly, Yolanda Gampel assigned the term "radioactivity" — which could here serve as yet another translation of snang $b a$-in order to explain the transgenerational nature a trauma that continues to cause psychological damage even in the future (Gampel 2003).

Ultimately, what is known as the "structural dissociation of personality" is grounded in the work of one of the most underestimated psychologists and philosophers of the twentieth century, namely Pierre Janet. Unlike many of today's psychologists, Janet understood dissociation not only as merely one of many symptoms in traumatized individuals, but rather an underlying organization of 
symptoms (Van der Hart et al. 2006, pp. 89-90)—what Janet called "systems of ideas and functions that constitute personality" (Janet 1907, p. 332). Predicated on this return to their discipline's founding figure, contemporary trauma researchers not only investigate specific manifestations of dissociative symptoms (such as depersonalization, derealization, or even just intense absorption, and imaginative involvement), ${ }^{9}$ but rather define "the essence of trauma" as a "structural dissociation of the personality" (Van der Hart et al. 2006, p. vii). "Structural dissociation," as the authors of The Haunted Self define the primary theme of their investigation, "is a particular organization in which different psychobiological subsystems of the personality are unduly rigid and closed to each other. These features lead to a lack of coherence and coordination within the survivor's personality as a whole" (Van der Hart et al. 2006, p. viii).

To fathom the dissociative division of the personality, it is imperative to recall our preceding discussion of attachment. In fact, structural dissociation only makes sense in light of the binary code with which children learn to relate to their environment, that is to say the approaching and avoiding categories of psychobiological or action systems. In other words, traumatic childhood experiences shape our mental models for the rest of our lives, so that the fragmentation of the self takes place along the fault lines of the psychobiological subsystems that are already prearranged due to our experiences and the evolution of humanity more generally (Van der Hart et al. 2004, 2006).

In concordance with the contradictory behavior of their early caretakers, fears of both attachment and of attachment loss have been found to become chronic symptoms amongst individuals that were traumatized as children. Van der Hart and his colleagues construe the psychological make-up of adults who were traumatized as children as follows:

Phobia of attachment is often paradoxically accompanied by an equally intense phobia of attachment loss. It manifests in desperate feelings and behaviors that motivate the individual to connect to another person at all costs. Typically, different parts of the personality experience these opposite phobias. They evoke each other in a vicious cycle, with a perceived change in closeness or distance in a relationship resulting in the well-known "borderline" pattern of "I hate you—don't leave me," more recently "described as disorganized/disoriented attachment. (Van der Hart et al. 2006, p. 14)

In the Great Perfection, this ambivalence of being one while simultaneously displaying a variety of contradictory mental models features prominently in the epiphany of the self. As we saw, the exteriorization of the ground involves the manifestation of entire worlds that include all sorts of beings, ultimately culminating in the mandala drawn from the eighth-century Guhyagarbha Tantra (Dalton 2013, p. 73).

At the moment of its climax, the ground manifests in the form of the famous five Buddhas known as Vairocana, Aksobhya, Ratnasambhava, Amitābha, and Amoghasiddhi. Chiefly, these deities take on two distinct forms: they are peaceful or wrathful. In other words, just as many trauma victims suffer from dissociative personalities, in which certain parts feel affection and attachment while others feel fear and aversion, the luminous visions that emerge out of the ground can be seen as something threatening and overwhelming or as something inviting and calming.

More generally speaking, scholarship has frequently spoken of the division within the Great Perfection as an issue of rhetoric. Sam van Schaik, for example, declares that "the Seminal Heart literature presents a pristine rhetoric interwoven with instructions on actual meditative practices that absorb and transform the practices of Mahāyoga and later Indic traditions"' (Van Schaik 2004).

This, however, underestimates not only the impact of trauma on the tradition but also its true internal division that was the result of its internalization. The internalization of trauma resulted in the tradition becoming a "dissociated totality," which consists of the following tension: on the one hand,

9 For an example of such an approach in the field of religious studies, see (Arzy and Idel 2015, p. 86). 
Dzogchen remained a unified tradition — what we could call a "totality" —of teachings that recognized themselves as belonging to the same movement. While Dzogchen changed over time, the tradition is said to have remained intact during this process of metamorphosis. Generally, the Great Perfection is said to have evolved first, then the Mind Series in the eighth century, and then, later, the Instruction Series around the eleventh and twelfth centuries.

On the other hand, although the Great Perfection aims to depict the growth of the tradition as an organic and unified process, from a historical-critical perspective, this is anything but apparent. On the contrary, Dzogchen thinkers responded to the trauma by appropriating teachings from the New Schools that stood in radical opposition to the tradition's earlier orientation. This led to a rupture within the totality, which we could define as "dissociation." While the little-known space series was quickly eclipsed, the Seminal Heart, which corresponds to the Instruction Series and rose to prominence between the eleventh and twelfth centuries, incorporates central elements drawn from the scriptures written in the previous centuries as part of the Mind Series Great Perfection, but also diverges dramatically in other ways. If the Mind Series is steeped in the rhetoric of negation, spontaneity, and the complete absence of technique, the Instruction Series scriptures display a plethora of meditative techniques, visionary manifestations, subtle body theories, and a cosmology crawling with peaceful and violent deities.

In short, during the age of the Renaissance of Tibetan culture, the Great Perfection manifested as a religious movement that is almost schizophrenic in nature: on the one hand, it abhors any form of religious activity, celebrating simplicity and naturalness as its highest accomplishments; on the other hand, it is an unmistakably tantric tradition, whose emphasis rests on the manipulation of a complex subtle anatomy and elaborate visionary meditations. ${ }^{10}$

\section{The Perpetuation of Trauma and the Conservative Turn of the Crown Pith}

From a historical angle, it must be mentioned that, while the eleventh and twelfth centuries witnessed the experimentation with a great breadth of religious movements, within and outside of the Ancient School, the emergence of the Seminal Heart caused a rare dilemma: the terms, content, and priorities of the newly emergent teachings were nowhere to be found in the earlier Great Perfection. Neither in the Mind Series scriptures, nor in the commentarial literature of Nubchen Sangye Yeshe (gnubs chen sangs rgyas ye shes, ninth century), nor of Rongzom Chökyi Zangpo (rong zom chos kyi bzang po, 1040-1159), do we find discussions of visionary practices, subtle bodies, embryology, or violent deities.

Particularly during the twelfth century, this discrepancy led to increasing controversies regarding the true nature of the Great Perfection. In an attempt to legitimize its own teachings, the Seminal Heart celebrated its own innovations as animated by intelligence and insights, while taking a more ambivalent stance towards the earlier occurrences in the Great Perfection. In fact, if we read the mythic narratives found in the Seminal Heart scriptures-in particular the allegories (lde' $u$ ) that complement the myth of the epiphany of the ground-as historical documents, it becomes apparent that they reflect a socio-political context of social struggle and competition. In those narratives, we find that the emergence of the cosmos continues in less than harmonious ways, as life on earth is recounted in the narratives of young children, mothers and fathers, old women and grandmothers, friendly and warring soldiers, and so forth.

10 Two points must be made here: first, it must be noted that such tensions were also present in other Buddhist traditions during those years. Consider, for example, Jacob Dalton's comments on early Mahāyoga (Dalton 2011), or Bernard Faure's identification of a similar tension within Chan Buddhism (Faure 1994). Second, the Great Perfection meditation practices are generally described as effortless and thus explicitly juxtaposed with the tantric practices of the New School. For a more comprehensive study of these meditative techniques, including their frequently underestimated tantric orientation, see (Geisshuesler 2019a). 
The most prominent example of these myths is found in The Tantra of Self-Arisen Awareness, where the dissociative scene is set by introducing an intelligent child and his dull-minded grandmother:

In the past, in a country known as "thoroughly pure awareness buddha field," there stood a castle with eight doors. On the top of this castle there lived a little boy whose name was "performing the awareness of epiphany" and his grandmother known as "cloudy eyed." In the lower part of this country, there lived a wicked king named "famous lord," who had five children. As the five princes went to amuse themselves and the grandmother "cloudy eyed" appeared down in the lower part for some rest, they put her into prison. Just imagine! Then, when her son went after his grandmother, he too was arrested and put into shackles. Just imagine! (RRS, 579.4-580.5) ${ }^{11}$

The child's name, which consists of the words to "perform" (byed) the "awareness" (rig) of the epiphany (snang $b a$ ), points to the little child's productive and energetic qualities that he shares with both the ground and the Seminal Heart tradition in their respective epiphanies. Guenther has meaningfully translated the son's name as "the inspiring youngster," emphasizing his excitability as the most differentiating characteristic. Even more relevantly, he points to the uneasy relationship between the little child and his care-takers as it is his excitability that distinguishes him from the unexcitability and unexcitation of his grandmother "cloudy eyed" (ling tog can) (Guenther 2005, pp. 124-25).

If we translate this into the logic of the historical development of the Great Perfection, we could say that the birth of the Seminal Heart corresponds to "performing the awareness of the epiphany" (khye'u snang ba'i rig byed), whereas the older strata of the Mind Series remains locked in a type of thinking that lacks vitality and insight. In other passages, the myths narrate the early life of little children as filled with hardship as they suffer at the hands of the older generation. In the thirty-ninth chapter of the same tantra, the scripture recounts two children's story as a dramatic abduction by figures standing close to them.

In the past, in a country known as "vastness," there existed a teacher by the name of "dispenser of light." He had two children, who had been imprisoned in a barren and deep ravine. Just imagine! Then, five soldiers appeared and conquered the stone castle from the top. Just imagine! After the two children had been thrown into a deep pit, grandmother "cloudy eyed" shut the door. Just imagine! (RRS, 560.6.) ${ }^{12}$

This narrative, short and abrupt—and consistently punctuated with the interjection "Just imagine" (zer te ya cha) - represents yet another anthropomorphization of the myth of the breaking of the vase. The two children are reified figures that contrast sharply with both the teacher and the kingdom in which they are born. Understood to be the siblings of a single mother, they stand for the epiphany of the ground, the rupture in the original unity of the primordial ground, and the multiplication that would ultimately form the universe as we know it. Finally, their imprisonment stands for humanity's straying as it mistakes its own identity and enters into the captivity of samsāra.

At the same time, the myth offers also a favorable symbolic processing of the Seminal Heart's version of the historical flowering of the Great Perfection. The Instruction Series, in all its innovative energy, emerged with its teachers, the Dispensers of Light-the personification of the sun ('od 'gyad $p a)$ - only to then be captured by representatives of earlier generations whose life energy had waned

11 sngon yul rnam par dag pa rig pa'i zhing khams zhes bya ba na/ mkhar sgo brgyad dang ldan pa'i mkhar zhig yod do/ mkhar de'i rtser khye'u snang ba'i rig byed bya ba yod/ de la ma rgan mo ling tog can zhes bya ba yod/yul de'i mda' na sdig/ spyod pa'i rgyal po grags pa dbang phyug bya ba de la bu rgyal bu lnga yod pas/ sras po lngas sku rtsed la song bas/ rgan mo ling tog can mdo na mar skyo sangs la byung bas/ sras rgyal bu lngas btson du bzung zer ba de ya cha/ de nas bu ma'i stegs ma la song ba yang bzung nas lcags su bcug zer ba te ya cha.

12 sngon yul yangs pa can zhes bya ba na/ ston pa 'od 'gyed pa zhes bya ba yod de/ de la bu spun gnyis yod pa/grog po stong par btson du bzung zer te ya cha/ de nas dmag mi lnga byung nas rdo' mkhar rtse nas bcom zer te ya cha/ bu gnyis dong du bcug nas rgan mo ling tog can gyis sgo bcad zer te ya cha. 
over the years. In light of such accounts of persecution due to creative energies, it is likely that the Renaissance period was an epoch of great religious diversity, but that even individual traditions like the Great Perfection were marked by intra-religious conflicts as they, too, lacked clear boundaries of definition in the fluidity of the period.

The cognitive perspective can help us to interpret these various types of self-assertion, competition, and conflict. In trauma research, the myth of the children's imprisonment corresponds closely to forms of disorganized attachment (Shemmings and Shemmings 2011, 2014; Solomon and George 2011). It is striking that the children are said to be betrayed by various figures standing close to them. In his commentary, written in the fourteenth century, the revealer Rigdzin Gödem Ngödrup Gyaltsen (rig 'dzin rgod ldem dngos grub rgyal mtshan, 1337-1408) of the Northern Treasures (byang gter) specifies, for example, that the soldiers were closely associated with the children, noting that they were originally jailed by "four disloyal friends" (DSR, 633-650).

Particularly, since episodes of betrayal by an attachment person have been systematically linked to an increased risk of traumatization (Benamer 2010; Liotti and Gumley 2008; Blizard 2003; Liotti 2006, 2009; Bettmann and Friedman 2013), attachment theory has also been taking on an increasingly prevailing role in research on trauma (Waelde et al. 2001; Freyd 1996). In the Handbook of Attachment, more precisely in a section entitled "Attachment and Dissociation," we read:

Early experiences with a frightened or frightening caregiver cause a child to develop multiple, incompatible models of the self and the other. In interactions with the caregiver, the child experiences rapid shifts in which the caregiver is at first frightened, then no longer frightened, then caring for the child. With each shift, a different model of self (perpetrator of fright, rescuer, loved child) and of the caregiver (victim, rescued victim, competent caregiver) is operative. These multiple models of the self and other cannot be integrated by young children and are retained as multiple models. (Cassidy and Shaver 2016, p. 722)

Attachment theorists mobilize experiments with young infants to show some prominently contradictory attitudes towards their primary caretakers, as they are unclear whether to love or hate them. Frequently, these children are displaying behavior that is marked by a tendency to both approach and flee at the same time. For instance, such children are seen to crawl backward towards their mother.

In the Seminal Heart's mythical world, this disorganized attachment is disclosed in the stories of abuse of children by attachment figures. In fact, it is relevant that the old woman known as "cloudy eyed," is repeatedly identified as the grandmother (a phyi). In the fortieth chapter of The Tantra of Self-Arisen Awareness, for instance, we read a story about a mother and a father who conceived two children, a girl and a boy. As the parents send the children away to the country of a demon to retrieve fire and flowers, the son refuses to go out of fear of being imprisoned by the demon. In response, the parents argue: "Son, don't say this. In the country of the demon (bdud), there lives an old woman called "cloudy eyed." She is your grandmother, ask her for fire" (RRS, 570.4). ${ }^{13}$ After requesting the support of five companions, the boy sets out to the country of the demon. Of course, as the boy himself predicted, he and his sister are immediately found by the demon, who has them detained.

So far so good, but now there comes a surprising twist in the story. While we do encounter the aforementioned grandmother, her demeanor towards her grandchildren is quite contrary to the parents' prediction.

Grandmother "cloudy eyed" locked the doors and told the attendants: "Because they killed my children in the past, do not let them escape." The servants responded: "It will be done so." There was no opportunity for them to leave. Then, the child spoke as follows: "Grandmother, my two [parents] told me that my grandmother by the name of "cloudy eyed" lives in the

13 yang pha ma gnyis na re 'od skad zer ro/ bu de skad ma zer bar bdud kyi yul na/ a phyi ling tog zhes bya ba yod kyis/ de khyod kyi a phyi yin gyis de la me slong la shog byas pas. 
country of the demon and they told me to ask for fire. Therefore, let me go without holding me [prisoner]." The old woman answered: "I will not let you go. I will not set you free because your father has killed my children." Then the boy responded: "If you don't let me go, I will raise an army." The woman responded: "Raise an army, I will not let you go." At that point, the youth passed along the following message to three visitors: "Friends, in the country "jewel heap," there are four outcasts. Your little child "intelligence of epiphany" has been imprisoned there. Swiftly bring a big army." The visitors, saying that they would do so, left (RRS, 572.2). ${ }^{14}$

This episode not only revisits previously encountered themes (such as the imprisonment of young children) and familiar characters (such as the little child "intelligence of epiphany", or the grandmother "cloudy eyed"), but it also offers new details about incarceration and the contact between the jailors and the captives. If I already set down that the trauma in Great Perfection narratives is personal and frequently grounded in family relationships, the plot gradually thickens as it becomes clear that trauma is a phenomenon that crosses generations. The grandmother not only imprisons her two grandchildren, but she also accuses them and their father of killing her own children.

Both individual and collective trauma, in fact, are frequently intergenerational in nature (Mucci 2013). Especially on a cultural level, trauma leaves traces that last for several generations (Yehuda et al. 2002). As Gilad Hirschberger put it:

Collective memory of trauma is different from individual memory because collective memory persists beyond the lives of the direct survivors of the events, and is remembered by group members that may be far removed from the traumatic events in time and space. These subsequent generations of trauma survivors, that never witnessed the actual events, may remember the events differently than the direct survivors, and then the construction of these past events may take different shape and form from generation to generation.

(Hirschberger 2018)

Indeed, it is a paradoxical characteristic of cultural trauma that its effects may actually increase over time, as the attribution of collective meaning to certain events can become more puissant from generation to generation (Klar et al. 2013).

The systematization of the Seminal Heart canon of scripture in the twelfth century also gave rise to opposing voices. The most potent of these was that of Nyangrel Nyima Özer (nyang ral nyi ma 'od ser, 1124/36-1192/1204), who capitalized on his role as a famous Treasure revealer (gter ston) to rehabilitate the ethos of the Mind Series as the highest form of teaching that Buddhism had to offer. Besides his fame as one of the architects of the cult of Padmasambhava and the Mahāyoga Eight Precept Deities ( $b k a^{\prime}$ brgyad) tradition, Nyangrel was also an imposing figure in the history of the Great Perfection (Doney 2014; Hirshberg 2016).

More specifically, Nyangrel was the central figure in the so-called Crown Pith (spyi ti) teachings. Although a new rubric, which emerged only in the twelfth century, the Crown Pith can be described as a nostalgic tradition that advocated for a return to the pristine teachings of the Mind Series. In contradistinction to the Seminal Heart tradition, which gradually included the tantric "alterity" into its own identity, the teachings revealed by Nyangrel—marked by an absence of tantric techniques and motifs of violence or sexuality—took a much more conservative stance. In this sense, the Crown

\footnotetext{
14 a phyi ling tog can gyis/ sgo lcags bcug nas/ 'khor rnams la sngon 'dis nga'i bu bsad pa yin pas 'di ma btang zhig byas pas/ 'khor rnams na re/ de ka ltar bgyi'o zer nas/'gro ba'i dbang ma byung ngo/ de nas yang bu des 'di skad ces byas so/ phyi bdag gi gnyis kyi zhal nas/ khyod kyi a phyi ling tog can bya ba de bdud kyi yul na yod kyis/ de nas me long la shog zer ba lags kyis/ bdag ma bzung bar thong byas pas/ rgan mos na re khyod mi btang ba yin/ nga'i bu khyod kyi phas bsad pa yin pas mi btang ngo zer ro/de nas bu des 'di skad ces byas so/ bdag mi btang na dmag 'dren byas pas/ mo na re/ khyod rang dmag drongs zer nas mthar ro/ de nas khos mgron po mi gsum la phrin btang ba/ kye grogs po dag/ yul rin chen spungs pa zhes bya ba na/ gdol pa'i rigs kyi mi bzhi yod kyis/ der khyod kyi khye'u rig byed btson du bzung bas/ dmag dpung mang po chos shig cig byas pas kho na re phrin bgyi'i zer nas song nog.
} 
Pith was "not merely a blind continuance of earlier traditions, [ . . ] but rather a type of conservative backlash against those developments" (Germano 2005, p. 23). Unsurprisingly, as Jean-Luc Achard noted, the Crown Pith view is explicitly identified with the youthful body in a vase and the Great Perfection ground (gzhi) before its epiphanic manifestation (gzhi snang), with all three of them being defined as "great original purity" (ka dag chen po) (Achard 2015).

Nyangrel was not only aware of the mythical narratives of the Seminal Heart, but also that they functioned as an implicit critique of older and/or more conservative forms of the Great Perfection teachings. He must have not only discerned that the Seminal Heart scriptures were filled with discussions of the breaking of the youthful body in a vase, the epiphany of the ground, and the adventurous self-exile of the young children, but must have also understood that these emphases are tantamount to an endorsement of the tradition and its schismatic tendencies. In fact, like the ground's luminous self-radiation or the children's invasion of new lands, the Seminal Heart disrupts the unity of the Great Perfection tradition, disrupting the boundaries of simplicity and harmony by experimenting with tantric materials that were previously kept outside of the boundaries of the tradition's membranes of selfhood.

It is also likely that Nyangrel himself held a different position and that he was critical of this attempt to redefine the boundaries of the Great Perfection, fearing that it would threaten the fragile homeostatic climate created over previous centuries. This becomes discernible if we consider that the Crown Pith scriptures respond to the Seminal Heart's symbolic attacks by relying on the same exact allegories. If the latter tries to vilify the early Mind Series by spinning narratives of disorganized attachment and abusive grandmothers, Nyangrel performs a reversal by celebrating the earlier tradition with metaphors of bonding, intimacy, and love.

Not unlike other forms of Buddhism, such as the Perfection of Insight sūtras (Conze 1967; Hixon 1993; Edou 1996, pp. 6, 28; Lopez 1996) or the Kālacakratantra (Wallace 2001, pp. 187-90), the Crown Pith celebrates the mother and has rightly been portrayed as "matrifocal" religious movement (Guenther 1996, p. 139). As a consequence, the texts in question regard the "epiphany of the self" not primarily as locus of trauma and loss of attachment, but rather as having potential for continued nurturing. In the Quintessence of the Sun and the Moon Tantra, for example, we find a depiction of the cosmos as a tripartite structure, which, although it evolved out of the "Sovereign Lady" (bdag mo), the cosmic queen (srid pa'i rgyal mo), the "mother" (yum), nonetheless remains stable and steady.

Then there is the sovereign Lady of the entire phenomenal world, the origin of all living beings, the mother, the cosmic queen, the great queen (bdag mo) of the whole all-ground. Although the living beings of the world are born from her, they do not increase in numbers, and although all that are born die, they do not decrease in numbers. Furthermore, there is nothing that grows, nothing that diminishes, nothing that is exhausted, nothing that is completed, and nothing that becomes empty. This is very wondrous (NZS, 29a). ${ }^{15}$

The Crown Pith scriptures, moreover, do not only anthropomorphize the mother, but also her children. In the previously cited tantra, for example, we also find an exceedingly poetic passage that speaks of how, out of the union of the archetypal mother (yum) and the archetypal father (yab), a son is born:

Further, in the temple "empty radiance of the sky's expanse," the stainless self-radiant little child dressed himself in a garment of light, made the five-colored rainbow his belt, put the clouds as a hat on his head, pushed his spurs against the wind [which acted as his horse], and poured ripples of water [like a bridle] into the mouth. In the right hand, he brandished his

15 de nas snang srid thams cad kyi mnga'i bdag mo/ sems can thams cad kyi ‘byung gnas yum srid pa'i rgyal mo/ kun gzhi kun gyi dbag mo che bya ba de las srid pa'i sems can skyes kyang sems can mang du ma song la/ skyes pa thams cad shi yang nyung du ma song skad de/ de yang 'phel ba'm zad pa dang/gang ba dang/ stongs pa yang med do/ de yang shin tu ngo mtshar che'o. 
swirling sword, completely eliminating any errors ('khrul pa) that had arisen. In the left one, he held up the lamp of the sun, clearing away the obscuring covers of ignorance. Drinking the nectar of immortality, he united the epiphanies and the world in equality (NZS, 29a). ${ }^{16}$

The "little child" (khye'u chung) is a prominent figure throughout the Crown Pith literature. The term khye' $u$ is a diminutive, which means "little child;" the adjective chung signifies "small." Furthermore, if the mother is usually identified with the ground, the child is most often associated with the "epiphany" (snang). In another tantra of the Great Perfection, The Symbol of the Secret Seminal Nuclei Tantra, where the allegorical narrations of the ground and its epiphany are attributed to Vimalamitra, the figure is known under various names, such as the "little child crystal" (shel gyi khye' $u$ ), "the eyes of the sun" (nyi ma'i spyan), "the little child youth" (khye'u chung gzhon nu), "sky embryo" (nam mkha'i snying po), "thoroughly radiating" (kun tu gsal gyis), or "little child of the inconceivable epiphany" (snang ba bsam gyis mi khyab pa) (TGB, 25: 49b-53a).

In The Tantra of the Kissing of the Epiphany and the World, the only Crown Pith scripture which carries the name of Nyangrel as treasure revealer in its colophon, we find a description of how the father, mother, and son were living in a castle known as "invariant concentration of the three aspects of the creation and perfection stage." There, so the scripture explains, "the lord and the lady of this castle, the all-good-father and mother, father and the mother, had a child named innate lucidity precious light" (SSK, 251b-252a). ${ }^{17}$

In what is probably the root tantra of the Crown Pith tradition, the father and the mother, pictured as "lord" (bdag po) and "lady" (bdag mo), provide their child with healthy attachment by virtue of themselves possessing a sense of "self" (bdag). Although the "son" (bu) is distinguished from both "mother" ( $m a)$ and "father" ( $p h a)$ through his playfully sparkling nature, he remains nonetheless connected to their grounded energy. The term ngang dwangs-literally translatable as "ongoing luminosity"-is brought into play to envision the "precious light" (rin chen 'od) which refers to the expressive quality of the ground's light.

In Nyangrel's mythic narratives, the bond of intimacy between parents and children is not premised on abuse and rupture, but rather continued connection and nurturing. Here, I am not suggesting that this figure was not affected by trauma, but rather that his response took on a different form. As if he wanted to counteract the schismatic impulses of the Seminal Heart scripture's endorsement of rupture, exploration, and conflict, Nyangrel's counterreading of the myth reveals his intention to maintain boundaries, protect harmony, and keep order.

Again, the cognitive sciences can offer us some insights into Nyangrel's readings of the myth. Scholars of attachment know that, particularly for children, who are the most vulnerable because of their complete dependence on their primary caretakers, comfort, support, and stability are crucial for the flourishing of physically and mentally healthy individuals (Runtz and Schallow 1997; Schore 2003; Slatcher and Selcuk 2017), just as healthy attachment involves parental attunement-the mirroring of the child's behavior through gestures, facial expressions, and voice-in order for children to develop a clear sense of their own selves, to familiarize themselves with their sensations, and to learn to regulate their emotions (Fonagy et al. 2002; Gergely and Watson 1999; Holmes 2001), Nyangrel enunciates the positive potential of the ground as motherhood.

In The Blazing of the Sun and the Moon Tantra, another scripture attributed to Padmasambhava and the Crown Pith, we find a similar image of a "quintessence that is a mother, whose nature is unwavering" (snying po ma yi rang bzhin g.yos pa med), on the one hand, and a "branch that is the

16 yang nam mkha'i dbyings stong gsal gyi lha khang na/ dri med rang gsal gyi khye'u chung bya ba des/ 'od kyi na bza' gsol/ 'ja' tshon sna lngas ska rags byas/ sprin gyi zha gon/ rlung po rkad tham mnan/ chu gnyer khar blugs/ phyag gsas su mtshon cha' $\mathrm{i}$ 'khor lo bskor nas/ 'khrul pa gang skyes thams cad rtsad nas bcad/g.yon du nyi ma'i sgron me thogs nas ma rig pa' $i$ sgrib g.yogs bsal/ bdud rtsi'i bcud 'thungs pas snang srid mnyam par sbyar.

17 bskyed rdzogs rnam gsum mi 'gyur bsam gtan mkhar/ mkhar khang gnyis kyi bdag po bdag mo ba/ kun bzang yab yum pha ma la/ bu ni ngang dwangs rin chen 'od. 
son, who without knowing engages into a multitude of objects" (yan lag bu yis ma rtogs sna tshogs yul la 'jug), on the other (NZB, 253ab). Ultimately, it must be reiterated that the codependent and mutually determining nature of the intimacy between child and mother is a central theme of reflection throughout the Crown Pith scriptures. In the aforementioned Quintessence of the Sun and the Moon Tantra, for example, we find two lines that perfectly express that mutual attachment:

That which makes a mother a "mother" is the child,

and that which makes a child a "child" is the mother (NZS, 24b). ${ }^{18}$

\section{Conclusions}

The Crown Pith never developed into a religious movement beyond Nyangrel and his immediate disciples and was all but forgotten in light of the dominance of the Seminal Heart. As part of their narrative, the Seminal Heart exegetes presuppose earlier developments and portray themselves as the authoritative interpreters of these teachings. For instance, with the emergence of the new scriptures, they retroactively classified the earlier tradition as the Mind Series, with one of the early mentions of the term being found in one of the most important of the Seminal Heart scriptures, namely The Reverberation of Sound Tantra. Similarly, the All-Creating King Tantra, the most famous text of the Mind Series, has been integrated in the Seminal Heart through the elaborate commentary by Longchenpa in the fourteenth century.

While existing scholarship tends to speak of these strategies as rhetorical operations, this study has attempted to show the powerful functions of myths within the Great Perfection. Taking the reader on a journey through the Seminal Heart's mythical narratives from the breaking of the youthful body in a vase to the internal dynamics of children and their (grand)mothers, I demonstrated how the tradition gradually processed, internalized, and ultimately perpetuated the historical trauma that it suffered. Knitting my own narrative by weaving in and out of history and myth, I showed that the Seminal Heart's stories were not only a means to respond to socio-political trauma but were also appropriated as weapons used to perpetuate new forms of domination and marginalization.

In this paper, I attempted to apply a transdisciplinary approach that integrates familiar techniques from religious studies (e.g., textual-historical research) with emergent insights from psychology and the cognitive sciences. This methodological orientation offered me the opportunity to shed new light on the concreteness of the tensions within the mythical heritage of the Great Perfection. The tradition's uneasy evolution into a dissociated totality of teachings can be visualized as the result of a vicious cycle in which attachment trauma results in dissociation, before giving rise to new forms of trauma through disorganized attachment. Considering that the twelfth-century conflict with the Crown Pith has been all but forgotten and that the Seminal Heart became so dominant that it is virtually synonymous with the Great Perfection itself, it could be argued that the myths contained in The Seventeen Tantras represented an effective means to silence its opposition.

Funding: This research was funded by the U.S. Department of Education, grant number P022A150029.

Conflicts of Interest: The author declares no conflict of interest.

\section{References}

\section{Tibetan Sources}

The Seventeen Tantras

The scriptures from the Seventeen Tantras are cited from the three-volume edition published by Sanje Dorje (1973) in New Delhi, based on the Adzom Drukpa blocks.

18 ma gnad bu la bu gnad ma/ ma bu dbyer med dgos don gnad. 
DJS-The Mirror of the Heart of Vajrasattva (rdo rje sems dpa' snying gi me long; vol. 1, 315-88).

GTG-The Reverberation of Sound Tantra (rin po che 'byung bar byed pa sgra thal 'gyur chen po'i rgyud; vol. 1, 1-205).

KSD-The Tantra of Great Beauty and Auspiciousness (bkra shis mdzes ldan chen po'i royud; vol. 1, 207-32).

LDG-The Six Spaces Tantra (kun tu bzang po klong drug pa'i rgyud; vol. 2, 111-214).

MTP-The Pearl Necklace Tantra (Mu tig rin po che phreng ba'i rgyud; vol. 2, 417-537).

RRS-The Tantra of Self-Arisen Awareness (rig pa rang shar chen po'i rgyud; vol. 1, 389-855).

SGT-The Tantra of the Lion's Perfect Expressive Energy (Seng ge rtsal rdzogs chen po'i rgyud; vol. 2, 245-415).

Some of these tantras have recently been translated into English:

Cornu, Philippe. 1997. Le Miroir Du Coeur. Tantra Du Dzogchen. Translated by Philippe Cornu. Seuil.

Smith, Malcolm. 2018. The Self-Arisen Vidyā Tantra: A Translation of the Rigpa Rangshar.

Smith, Malcolm. 2020. The Blazing Lamp Tantra and The Threaded String of Pearls: A Translation of the Drönma Barwai Gyü and The Mutik Trengwa Gyüpa. Somerville: Wisdom Publications with Zangthal Editions.

The Crown Pith Tantras

NZB - The Blazing of the Sun and the Moon Tantra (Full title: The Blazing Sun and Moon Tantra Dispelling the Darkness of Non-Awareness, The Unified Quintessence of Original Purities' Esoteric Meaning, The Encapsulated Quintessence of the Ultra Core Wisdom of the Enlightened Mind, thugs kyi yang snying dgongs pa'i bcud 'dus pa/_ka dag rnams kyi gsang don bcud dril pa/_ma rig mun sel nyi zla 'bar ba'i rgyud, sDe-dge edition; vol. 2: 343a-351b).

NZS-Quintessence of the Sun and the Moon Tantra (full title: The King of All Tantras: The Tantra of the Swirling Lake of Ambrosia Blazing with the Quintessence of the Sun and the Moon, rGyud thams cad kyi royal po nyi zla'i snying po 'od 'bar ba bdud rtsi'i rgya mtsho 'khyil ba'i rgyud, sde dge edition, vol. 3, 18b-46b).

SSK-The Tantra of the Kissing of the Epiphany and the World (Full title: The Tantra of the Cyclic Existence Eradicating Ambrosial Drops Kissing of the Epiphany and the World, snang srid kha sbyor: sNang srid kha sbyor bdud rtsi bcud thigs 'khor ba thog mtha' gcod pa'i rgyud, sde dge edition, vol. 2, 204a-265b).

The Vimalamitra Tantras:

DYC - The Conch Shell Lettered (Dung Yig Can), is authored by Vimalamitra, and in the main is a systematic survey of each of The Seventeen Tantras (VNT2 1-159);

In VNT, The Conch Shell Lettered by Vimalamitra (VNT2 1-159) provides a very interesting and heavily annotated analysis of each Tantra, including etymologies of their titles, discussions of their internal divisions and so forth.

TGB - The Symbol of the Secret Seminal Nuclei Tantra (thig le gsang ba'i brda' rgyud, sde dge edition, vol. 25, 107-8.

Rigdzin Gödem

DSR - The Tantra on the Difference Between Mind and Awareness According to the Great Perfection (rDzogs-pa-chen-po sems dang rig-pa dbye-ba'i rgyud). In the The Unimpeded Realization of Samantabhadra (kun tu bzang po'i dgongs pa zang thal). Dgongs-pa zang-thal, vol. 2, pp. 633-50.

\section{Secondary Literature}

Abelow, Benjamin J. 2011. The Shaping of New Testament Narrative and Salvation Teachings by Painful Childhood Experience. Archive for the Psychology of Religion 33: 1-54. [CrossRef]

Achard, Jean-Luc. 1999. L'essence perlée du secret: recherches philologiques et historiques sur l'origine de la Grande Perfection dans la tradition rNying ma pa. Turnhout: Brepols.

Achard, Jean-Luc. 2005. Le mode d'émergence du Réel — les manifestations de la Base (gzhi snang) selon les conceptions de la Grande Perfection. Revue d'Etudes Tibétaines 7: 64-96.

Achard, Jean-Luc. 2008. L'irruption de la nescience - la notion d'errance samsārique dans le rDzogs chen. Revue d'Etudes Tibétaines 13: 75-108.

Achard, Jean-Luc. 2012. Zhang Ston BKra Shis Rdo Rje (1097-1167) et La Continuation Des Essences Perlées (SNying Thig) de La Grande Perfection. In This World and the Next: Contributions on Tibetan Religion, Science and Society. Andiast: Tibet Institut, pp. 233-66.

Achard, Jean-Luc. 2015. The View of Spyi-Ti Yoga. Revue d'études Tibétaines (RET) 31: 1-20. 
Adonis, Cyril Kenneth. 2016. Exploring the Salience of Intergenerational Trauma among Children and Grandchildren of Victims of Apartheid-Era Gross Human Rights Violations. Indo-Pacific Journal of Phenomenology 16: 163-79. [CrossRef]

Alexander, Jeffrey C. 2004. Toward a Theory of Cultural Trauma. In Cultural Trauma and Collective Identity. Edited by Jeffrey C. Alexander, Ron Eyerman, Bernard Giesen, Neil J. Smelser and Piotr Sztompka. Berkeley: University of California Press, pp. 1-30.

Alexander, Jeffrey C. 2012. Trauma: A Social Theory. Cambridge: Polity Press.

Arguillère, Stéphane. 2007. Profusion de la vaste sphère: Klong-chen rab-'byams (Tibet, 1308-1364). Sa vie, son oeuvre, sa doctrine. Orientalia Analecta Lovaniensa 167. Leuven: Peeters Publishers.

Arnold, Magda B. 1960. Emotion and Personality. New York: Columbia University Press.

Arzy, Shahar, and Moshe Idel. 2015. Kabbalah: A Neurocognitive Approach to Mystical Experiences. New Haven: Yale University Press.

Bargh, John A. 2017. Before You Know It: The Unconscious Reasons We Do What We Do. New York: Touchstone.

Benamer, Sarah. 2010. Telling Stories?: Attachment-Based Approach to the Treatment of Psychosis. London: Karnac.

Bettmann, Joanna E., and Donna Demetri Friedman. 2013. Attachment-Based Clinical Work with Children and Adolescents. New York: Springer.

Birnbaum, Aiton. 2008. Collective Trauma and Post-Traumatic Symptoms in the Biblical Narrative of Ancient Israel. Mental Health, Religion \& Culture 11: 533-46. [CrossRef]

Blizard, Ruth A. 2003. Disorganized Attachment, Development of Dissociated Self States, and a Relational Approach to Treatment. Journal of Trauma \& Dissociation 4: 27-50. [CrossRef]

Bombay, Amy, Kimberly Matheson, and Hymie Anisman. 2017. Perspectives on Intergenerational Transmission of Trauma: The Case of Aboriginal Peoples in Canada. In Social Issues in Living Color: Challenges and Solutions from the Perspective of Ethnic Minority Psychology: Promoting Health and Well-Being. Santa Barbara: Praeger/ABC-CLIO, vol. 3, pp. 171-96.

Cabezón, José Ignacio. 2013. The Buddha's Doctrine and the Nine Vehicles: Rog Bande Sherab's Lamp of the Teachings. New York: Oxford University Press.

Carlson, Elizabeth A., Tuppett M. Yates, and L. Alan Sroufe. 2009. Dissociation and Development of the Self. In Dissociation and the Dissociative Disorders: DSM-V and Beyond. New York: Routledge/Taylor \& Francis Group, pp. 39-52.

Caruth, Cathy. 1995. Trauma: Explorations in Memory. Baltimore: Johns Hopkins University Press.

Caruth, Cathy. 2016. Unclaimed Experience: Trauma, Narrative, and History. Baltimore: Johns Hopkins University Press.

Cassidy, Jude, and Phillip R. Shaver. 2016. Handbook of Attachment: Theory, Research, and Clinical Applications. New York: Guilford Press.

Conze, Edward. 1967. The Development of Prajnaparamita Thought. In Thirty Years of Buddhist Studies: Selected Essays. Oxford: B. Cassirer, pp. 123-47.

Dalenberg, Constance J., Bethany L. Brand, David H. Gleaves, Martin J. Dorahy, Richard J. Loewenstein, Etzel Cardeña, Paul A. Frewen, Eve B. Carlson, and David Spiegel. 2012. Evaluation of the Evidence for the Trauma and Fantasy Models of Dissociation. Psychological Bulletin 138: 550-88. [CrossRef]

Dalton, Jacob P. 2011. The Questions and Answers of Vajrasattva. In Yoga in Practice. Edited by David Gordon White. Princeton: Princeton University Press, pp. 185-203.

Dalton, Jacob P. 2013. The Taming of the Demons: Violence and Liberation in Tibetan Buddhism. New Haven: Yale University Press.

Davidson, Ronald M. 2005. Tibetan Renaissance: Tantric Buddhism in the Rebirth of Tibetan Culture. New York: Columbia University Press.

Debs, Mira. 2013. Using Cultural Trauma: Gandhi's Assassination, Partition and Secular Nationalism in Post-independence India. Nations and Nationalism 19: 635-53. [CrossRef]

Deroche, Marc-Henri, and Akinori Yasuda. 2015. The RDzogs Chen Doctrine of the Three Gnoses (Ye Shes Gsum): An Analysis of Klong Chen Pa's Exegesis and His Sources. Revue d'Etudes Tibétaines 33: 187-230.

Doney, Lewis. 2014. The Zangs Gling Ma: The First Padmasambhava Biography. Two Exemplars of the Earliest Attested Recension. Monumenta Tibetica Historica. Vitae. Andiast: IITBS GmbH, International Institute for Tibetan and Buddhist Studies. 
Durà-Vilà, Glòria, Roland Littlewood, and Gerard Leavey. 2013. Integration of Sexual Trauma in a Religious Narrative: Transformation, Resolution and Growth among Contemplative Nuns. Transcultural Psychiatry 50: 21-46. [CrossRef]

Edou, Jérôme. 1996. Machig Labdrön and the Foundations of Chöd. Ithaca: Snow Lion.

Eyerman, Ron. 2001. Cultural Trauma: Slavery and the Formation of African American Identity. Cambridge: Cambridge University Press.

Faure, Bernard. 1994. The Rhetoric of Immediacy: A Cultural Critique of Chan/Zen Buddhism. Princeton: Princeton University Press.

Fonagy, Peter, Gyorgy Gergely, Elliot Jurist, and Mary Target. 2002. Affect Regulation, Mentalization, and the Development of the Self. New York: Other Press.

Freyd, Jennifer J. 1996. Betrayal Trauma: The Logic of Forgetting Childhood Abuse. Cambridge: Harvard University Press. Frijda, Nico H. 1986. The Emotions. Cambridge: Cambridge University Press.

Gampel, Yolanda. 2003. Reflections on the Prevalence of the Uncanny in Social Violence. In Cultures under Siege: Collective Violence and Trauma. Edited by Antonius C. G. M. Robben and Marcelo M. Suárez-Orozco. Cambridge: Cambridge University Press, pp. 48-69.

Gayley, Holly. 2017. Love Letters from Golok: A Tantric Couple in Modern Tibet. New York: Columbia University Press. Geisshuesler, Flavio A. 2019a. Prisons of Freedom: An Interdisciplinary Study of Contemplative Practices in Great Perfection Buddhism. Charlottesville: University of Virginia.

Geisshuesler, Flavio A. 2019b. When Buddhas Dissociate: A Psychological Perspective on the Origins of Great Perfection Buddhism (RDzogs Chen). Cogent Psychology 6: 1707055. [CrossRef]

Gergely, György, and John S. Watson. 1999. Early Socio-Emotional Development: Contingency Perception and the Social-Biofeedback Model. In Early Social Cognition: Understanding Others in the First Months of Life. Mahwah: Lawrence Erlbaum Associates Publishers, pp. 101-36.

Germano, David. 1992. Poetic Thought, the Intelligent Universe, and the Mystery of Self: The Tantric Synthesis of rDzogs Chen in Fourteenth Century Tibet. Ph.D. dissertation, University of Wisconsin, Madison, WI, USA.

Germano, David. 1994. Architecture and Absence in the Secret Tantric History of rDzogs Chen. Journal of the International Association of Buddhist Studies 17: 203-335.

Germano, David. 2005. The Funerary Transformation of the Great Perfection (rDzogs chen). Journal of the International Association of Tibetan Studies 1: 1-54.

Giesen, Bernhard. 2004. The Trauma of Perpetrators: The Holocaust as the Traumatic Reference of German National Identity. In Cultural Trauma and Collective Identity. Edited by Jeffrey C. Alexander, Ron Eyerman, Bernard Giesen, Neil J. Smelser and Piotr Sztompka. Berkeley: University of California Press, pp. 112-54.

Guénard, Frédéric, Yves Deshaies, Katherine Cianflone, John G. Kral, Picard Marceau, and Marie-Claude Vohl. 2013. Differential Methylation in Glucoregulatory Genes of Offspring Born before vs. after Maternal Gastrointestinal Bypass Surgery. Proceedings of the National Academy of Sciences 110: 11439-44. [CrossRef] [PubMed]

Guenther, Herbert V. 1996. The Teachings of Padmasambhava. Leiden: Brill.

Guenther, Herbert V. 2005. Down and Up Again: Allegories of Becoming and Transcendence. Published Electronically by the Author. Available online: http://www.buddhistischer-studienverlag.de/shop/downloads/DownUp.pdf (accessed on 7 March 2020).

Gyatso, Janet B. 1998. Apparitions of the Self: The Secret Autobiographies of a Tibetan Visionary. Princeton: Princeton University Press.

Hamilton, Claire E. 2000. Continuity and Discontinuity of Attachment from Infancy through Adolescence. Child Development 71: 690-94. [CrossRef] [PubMed]

Hanif, Samia, and Inayat Ullah. 2018. War Trauma, Collective Memory, and Cultural Productions in Conflict Zones: Kashmir in Focus. SAGE Open 8: 2158244018800912. [CrossRef]

Hatchell, Christopher. 2014. Naked Seeing: The Great Perfection, the Wheel of Time, and Visionary Buddhism in Renaissance Tibet. New York: Oxford University Press.

Hesse, Erik, and Mary Main. 2000. Disorganized Infant, Child, and Adult Attachment: Collapse in Behavioral and Attentional Strategies. Journal of the American Psychoanalytic Association 48: 1097-127, discussion 1175-87. [CrossRef] 
Higgins, David. 2013. The Philosophical Foundations of Classical rDzogs Chen in Tibet: Investigating the Distinction between Dualistic Mind (sems) and Primordial Knowing (ye shes). Wiener Studien zur Tibetologie und Buddhismuskunde 78. Vienna: Arbeitskreis für Tibetische und Buddhistische Studien.

Hirschberger, Gilad. 2018. Collective Trauma and the Social Construction of Meaning. Frontiers in Psychology 9: 1441. [CrossRef]

Hirshberg, Daniel A. 2016. Remembering the Lotus-Born: Padmasambhava in the History of Tibet's Golden Age. Studies in Indian and Tibetan Buddhism. Somerville: Wisdom Publications.

Hixon, Lex. 1993. Mother of the Buddhas Meditation on the Prajnaparamita Sutra. Wheaton: Quest Books.

Holmes, Jeremy. 2001. The Search for the Secure Base: Attachment Theory and Psychotherapy. Philadelphia: Brunner/Routledge.

Hussain, Dilwar, and Braj Bhushan. 2011. Cultural Factors Promoting Coping among Tibetan Refugees: A Qualitative Investigation. Mental Health, Religion \& Culture 14: 575-87. [CrossRef]

Hussain, Dilwar, and Braj Bhushan. 2013. Posttraumatic Growth Experiences among Tibetan Refugees: A Qualitative Investigation. Qualitative Research in Psychology 10: 204-16. [CrossRef]

Janet, Pierre. 1907. The Major Symptoms of Hysteria. New York: Macmillan Publishing.

Kapstein, Matthew T. 1998. Buddhism in Contemporary Tibet: Religious Revival and Cultural Identity. Edited by Melvyn C. Goldstein. Berkeley: University of California Press.

Kapstein, Matthew T. 2000. The Tibetan Assimilation of Buddhism: Conversion, Contestation, and Memory. New York: Oxford University Press.

Karmay, Samten Gyaltsen. 2007. The Ancient Documents on rDzogs-chen from Tun-huang. In The Great Perfection (rDzogs chen): A Philosophical and Meditative Teaching of Tibetan Buddhism. Leiden and Boston: Brill, pp. 41-85.

Klar, Yechiel, Noa Schori-Eyal, and Yonat Klar. 2013. The 'Never Again' State of Israel: The Emergence of the Holocaust as a Core Feature of Israeli Identity and Its Four Incongruent Voices. Journal of Social Issues 69: 125-43. [CrossRef]

Kolas, Ashild, and Monika P. Thowsen. 2005. On the Margins of Tibet: Cultural Survival on the Sino-Tibetan Frontier (Studies on Ethnic Groups in China). Seattle: University of Washington Press.

LaCapra, Dominick, and Mazal Holocaust Collection. 1994. Representing the Holocaust: History, Theory, Trauma. Ithaca: Cornell University Press.

Liotti, Giovanni. 2006. A Model of Dissociation Based on Attachment Theory and Research. Journal of Trauma $\mathcal{E}$ Dissociation: The Official Journal of the International Society for the Study of Dissociation (ISSD) 7: 55-73. [CrossRef]

Liotti, Giovanni. 2009. Attachment and Dissociation. In Dissociation and the Dissociative Disorders: DSM-V and Beyond. New York: Routledge/Taylor \& Francis Group, pp. 53-65.

Liotti, Giovanni, and Andrew Gumley. 2008. An Attachment Perspective on Schizophrenia: The Role of Disorganized Attachment, Dissociation and Mentalization. In Psychosis, Trauma and Dissociation: Emerging Perspectives on Severe Psychopathology. Hoboken: Wiley-Blackwell, pp. 117-33.

Lopez, Donald S. 1996. Elaborations on Emptiness: Uses of the Heart Sutra. Princeton: Princeton University Press.

Lyons-Ruth, Karlen, Lissa Dutra, Michelle R. Schuder, and Ilaria Bianchi. 2006. From Infant Attachment Disorganization to Adult Dissociation: Relational Adaptations or Traumatic Experiences? The Psychiatric Clinics of North America 29: 63-86. [CrossRef]

Main, Mary, and Erik Hesse. 1990. Parents' Unresolved Traumatic Experiences Are Related to Infant Disorganized Attachment Status: Is Frightened and/or Frightening Parental Behavior the Linking Mechanism? In Attachment in the Preschool Years: Theory, Research, and Intervention. The John D. and Catherine T. MacArthur Foundation Series on Mental Health and Development; Chicago: University of Chicago Press, pp. 161-82.

Mazur, Lucas B., and Johanna Ray Vollhardt. 2016. The Prototypicality of Genocide: Implications for International Intervention. Analyses of Social Issues and Public Policy 16: 290-320. [CrossRef]

McGowan, Patrick O., Aya Sasaki, Tony C. T. Huang, Alexander Unterberger, Matthew Suderman, Carl Ernst, Michael J. Meaney, Gustavo Turecki, and Moshe Szyf. 2008. Promoter-Wide Hypermethylation of the Ribosomal RNA Gene Promoter in the Suicide Brain. PLoS ONE 3: e2085. [CrossRef]

Meaney, Michael J. 2001. Maternal Care, Gene Expression, and the Transmission of Individual Differences in Stress Reactivity across Generations. Annual Review of Neuroscience 24: 1161-92. [CrossRef]

Miller, Alice. 1981. Prisoners of Childhood: The Drama of the Gifted Child and the Search for the True Self. New York: Basic Books. 
Mittleman, Alan L. 1990. Between Kant and Kabbalah: An Introduction to Isaac Breuer's Philosophy of Judaism. Albany: State University of New York Press.

Morrison, Anthony P., Lucy Frame, and Warren Larkin. 2003. Relationships between Trauma and Psychosis: A Review and Integration. The British Journal of Clinical Psychology 42 Pt 4: 331-53. [CrossRef]

Mucci, Clara. 2013. Beyond Individual and Collective Trauma: Intergenerational Transmission, Psychoanalytic Treatment, and the Dynamics of Forgiveness. London: Karnac Books.

Newman, John. 1991. A Brief History of the Kalachakra. In The Wheel of Time: The Kalachakra in Context. Edited by Geshe Lhundub Sopa, Roger R. Jackson and John Newman. Ithaca: Snow Lion Publications, pp. 51-84.

Otto, Hiltrud, and Heidi Keller. 2014. Different Faces of Attachment: Cultural Variations on a Universal Human Need. Cambridge: Cambridge university press.

Perroud, Nader Ali, Andreas Salzmann, Paco Prada, Rosetta Nicastro, Marie-Eve Hoeppli, Stefan Furrer, Stefano Ardu, Ivo Krejci, Félicien Karege, and Alain Malafosse. 2013. Response to Psychotherapy in Borderline Personality Disorder and Methylation Status of the BDNF Gene. Translational Psychiatry 3: e207. [CrossRef]

Read, John, Paul Jay Fink, Thom Rudegeair, Vincent Felitti, and Charles L. Whitfield. 2008. Child Maltreatment and Psychosis: A Return to a Genuinely Integrated Bio-Psycho-Social Model. Clinical Schizophrenia \& Related Psychoses 2: 235-54. [CrossRef]

Rippl, Gabriele, Philipp Schweighauser, Therese Steffen, Tiina Kirss, and Margit Sutrop, eds. 2013. Haunted Narratives: Life Writing in an Age of Trauma. Toronto: University of Toronto Press.

Rodger, James, and Zachary Steel. 2016. Between Trauma and the Sacred: The Cultural Shaping of Remitting-Relapsing Psychosis in Post-Conflict Timor-Leste. Cham: Springer International Publishing.

Rong-zom Chos-kyi-bzang-po. 2017. Entering the way of the great vehicle: Dzogchen as the culmination of the Mahāyāna. Translated by Dominic Sur. Boulder: Snow Lion.

Runtz, Marsha G., and John R. Schallow. 1997. Social Support and Coping Strategies as Mediators of Adult Adjustment Following Childhood Maltreatment. Child Abuse \& Neglect 21: 211-26. [CrossRef]

Scharfetter, Christian. 2009. Ego-Fragmentation in Schizophrenia: A Severe Dissociation of Self-Experience. In Psychosis, Trauma and Dissociation. Edited by Andrew Moskowitz, Ingo Schäfer and Martin J. Dorahy. Hoboken: Wiley-Blackwell, pp. 51-64.

Schore, Allan N. 2003. Affect Regulation \& the Repair of the Self. New York: W.W. Norton.

Shemmings, David, and Yvonne Shemmings. 2011. Understanding Disorganized Attachment: Theory and Practice for Working with Children and Adults. London: Jessica Kingsley.

Shemmings, David, and Yvonne Shemmings. 2014. Assessing Disorganized Attachment Behaviour in Children: An Evidence-Based Model for Understanding and Supporting Families. London: Jessica Kingsley Publishers.

Sideris, Tina. 1998. Women and Apartheid. Collective Trauma and Social Reconstruction. The Way, 80-92.

Slatcher, Richard B., and Emre Selcuk. 2017. A Social Psychological Perspective on the Links between Close Relationships and Health. Current Directions in Psychological Science 26: 16-21. [CrossRef] [PubMed]

Solomon, Judith, and Carol George. 2011. Disorganized Attachment and Caregiving. New York: Guilford Press.

Tal, Kalí. 2004. Worlds of Hurt: Reading the Literatures of Trauma. Cambridge: Cambridge University Press.

Terheggen, Maaike A., Margaret S. Stroebe, and Rolf J. Kleber. 2001. Western Conceptualizations and Eastern Experience: A Cross-Cultural Study of Traumatic Stress Reactions Among Tibetan Refugees in India. Journal of Traumatic Stress 14: 391-403. [CrossRef] [PubMed]

Van der Hart, Onno, Ellert Nijenhuis, Kathy Steele, and Daniel Brown. 2004. Trauma-Related Dissociation: Conceptual Clarity Lost and Found. The Australian and New Zealand Journal of Psychiatry 38: 906-14. [CrossRef] [PubMed]

Van der Hart, Onno, Ellert R. S. Nijenhuis, and Kathy Steele. 2006. The Haunted Self: Structural Dissociation and the Treatment of Chronic Traumatization. New York: W.W. Norton.

Van Ijzendoorn, Marinus H., and Abraham Sagi-Schwartz. 1999. Cross-Cultural Patterns of Attachment: Universal and Contextual Dimensions. In Handbook of Attachment: Theory, Research, and Clinical Applications. New York: Guilford Press, pp. 713-34.

Van Schaik, Sam. 2004. The Early Days of the Great Perfection. Journal of the International Association of Buddhist Studies 27: 165-206. 
Waelde, Lynn C., Cheryl Koopman, Jill Rierdan, and David Spiegel. 2001. Symptoms of Acute Stress Disorder and Posttraumatic Stress Disorder Following Exposure to Disastrous Flooding. Journal of Trauma E Dissociation 2: 37-52. [CrossRef]

Wallace, Vesna. 2001. The Inner Kalacakratantra: A Buddhist Tantric View of the Individual. New York: Oxford University Press.

Yehuda, Rachel, Sarah L. Halligan, and Linda M. Bierer. 2002. Cortisol Levels in Adult Offspring of Holocaust Survivors: Relation to PTSD Symptom Severity in the Parent and Child. Psychoneuroendocrinology 27: 171-80. [CrossRef]

Yehuda, Rachel, Nikolaos P. Daskalakis, Linda M. Bierer, Heather N. Bader, Torsten Klengel, Florian Holsboer, and Elisabeth B. Binder. 2016. Holocaust Exposure Induced Intergenerational Effects on FKBP5 Methylation. Biological Psychiatry 80: 372-80. [CrossRef]

Yusin, Jennifer. 2009. The Silence of Partition: Borders, Trauma, and Partition History. Social Semiotics 19: 453-68. [CrossRef]

(C) 2020 by the author. Licensee MDPI, Basel, Switzerland. This article is an open access article distributed under the terms and conditions of the Creative Commons Attribution (CC BY) license (http://creativecommons.org/licenses/by/4.0/). 